Andrzej Wojtaszak

Uniwersytet Szczeciński

iD ORCID: 0000-0002-5615-9438
OBLICZA WOJNY

TOM 4 • MIASTO I WOJNA

ŁóDŹ2021 •ISBN 978-83-8220-617-3 • 5. 193-218

https://doi.org/10.18778/8220-617-3.11

\title{
WALKI O WILNO 19-21 KWIETNIA 1919 ROKU
}

Streszczenie. Wilno w okresie walk o granice Rzeczypospolitej po I wojnie światowej (do 1921), było zajmowane przez cztery armie: niemiecką (wojska Ober-Ostu), sowiecką, litewską i polską. Prezentowane opracowanie dotyczy walk o Wilno w kwietniu 1919 r. W ramach tzw. operacji wileńskiej oddziały grupy rajdowej kawalerii (1 Brygada Jazdy), dowodzone przez ppłk. Władysława Zygmunta Belinę-Prażmowskiego oraz 2 Dywizji Piechoty Legionów, dowodzone przez gen. Edwarda Śmigłego-Rydza, zajęły miasto. W trzydniowych walkach w mieście ważną rolę odegrali sami mieszkańcy, szczególnie kolejarze i robotnicy ze Stowarzyszenia Św. Kazimierza. Podjęte przez wojska polskie działania wynikały z ogólnych założeń ofensywy wileńskiej, opierały się na koncepcji szybkiego zagonu (rajdu) kawaleryjskiego, zaskoczeniu przeciwnika oraz zajęciu kluczowych dla dalszych walk istotnych obiektów miasta (stacja kolejowa, koszary, brzeg rzeki Wilii). Po trzech dniach, dzięki wsparciu 2 Dywizji Piechoty Legionów zajęto miasto. Doświadczenie walk o (dwustutysięczne) Wilno miało być wykorzystane w dalszym okresie wojny polsko-bolszewickiej. Samo miasto zostało zajęte w październiku 1921 r. (w wyniku „puczu") przez wojska dowodzone przez gen. Lucjana Żeligowskiego, od marca 1922 r. ostatecznie znalazło się w granicach II Rzeczypospolitej.

Słowa kluczowe: Wilno, taktyka walki, ofensywa wileńska, 2 Dywizja Legionów Polskich, 1 Brygada Jazdy, ppłk Władysław Belina-Prażmowski, gen. Edward Śmigły-Rydz, Józef Piłsudski

\section{Wprowadzenie}

Walki o kształt granic Rzeczypospolitej po I wojnie światowej toczyły się nieprzerwanie do 1921 r. (tzw. pokój ryski). O ile w przypadkach Galicji czy Wielkopolski, kierowali nimi doświadczeni generałowie z byłych armii państw zaborczych (np. Józef Dowbor-Muśnicki, Tadeusz Rozwadowski, a także - po powrocie do Polski Błękitnej Armii - gen. Józef Haller), o tyle pieczę nad 
trzecim frontem (Litewsko-Białoruskim), wiosną 1919 r. sprawował osobiście Józef Piłsudski ${ }^{1}$.

Od początku walk o granice wschodnie Rzeczypospolitej Naczelny Wódz starał się kontrolować wydarzenia dotyczące sytuacji politycznej i militarnej w rejonie Wilna i Wileńszczyzny. Na przełomie lat 1918 i 1919 na części tych terenów stacjonowały wojska niemieckie, tzw. Ober-Ostu, dowodzone przez gen. Maxa Hoffmanna. Obecność wojsk niemieckich utrudniała przejęcie tego obszaru przez stronę polską. Jednym z rozwiązań, mogło być przepuszczenie przez Niemców Wojska Polskiego (WP) w rejon Wilna (forma korytarza), na co strona niemiecka nie wyrażała początkowo zgody. W grudniu $1918 \mathrm{r}$. Sztab Generalny WP opracował plan okupacji ziem litewsko-białoruskich ${ }^{2}$.

Naczelnik Państwa i rząd polski opowiadali się za realizacją koncepcji federacyjnej na wschodnich terenach dawnej Rzeczypospolitej. Tworzyć ją miały połączone ze sobą więzami handlowymi i umowami międzynarodowymi Polska, Litwa, Białoruś, skonfederowana z tą unią miała być niepodległa Ukraina. Chcąc uporządkować relacje z Litwinami i mieć wpływ na sytuację na kresach wschodnich, Piłsudski liczył na to, że zdoła zbudować federację państw środkowoeuropejskich, która będzie w stanie przeciwstawić się Rosji³

Widząc niepewność sytuacji polityczno-militarnej, inicjatywę na obszarze Wileńszczyzny przejęli Polacy, byli wojskowi wywodzący się z armii carskiej. Generał Władysław Wejtko, opierając się na powstających oddziałach samoobrony (dwa pułki piechoty i pułk jazdy), utworzył Okręg Wojskowy Litwy i Białorusi, którego został dowódcą ${ }^{4}$.

Oddziały dowodzone przez gen. Wejtko zajęły Wilno, co spowodowało protesty ze strony Litwinów. Na litewską notę protestacyjną (4 I 1919) zareagował prezydent ministrów (i minister spraw zewnętrznych) Ignacy Jan Paderewski (12 I 1919). Odpowiadając na litewską notę pisat:

${ }^{1}$ K. ŚLEDZIŃSKI, Wojna polsko-bolszewicka. Konflikt, który zmienit bieg historii, Kraków 2020, s. 112.

2 Vide: L. Wyszczelski, Wilno 1919-1920, Warszawa 2008, s. 16.

3 Polski dyplomata Aleksander Ładoś o koncepcji federacyjnej pisał: „Widziała ona rozwiązanie kwestii polskiej na wschodzie, przez utworzenie kilku, związanych z Polską, demokratycznych republik, a to ukraińskiej, białoruskiej, litewskiej, obejmujących te historycznie związane z Polską narody w ich etnicznych granicach" - A. ŁADoś, Wasilewski wrokowaniach ryskich. (Wspomnienia osobiste), „Niepodległość” 1937, t. 16, s. 233.

${ }^{4}$ W. Wejt ko, Samoobrona Litwy i Biatorusi. Szkice historyczne, Wilno 1930, s. 69 i n. (zał. $\operatorname{nr} 6)$. 
Rząd Polski nie może uznać Państwa Litewskiego w tej formie i w tych granicach w jakich chciałby je widzieć dzisiaj Rząd Litewski. Rząd polski jest zdania, że kwestia granic pomiędzy ewentualnym państwem litewskim a polskim powinna być uregulowana na podstawie swobodnie wyrażonej woli ludności, zamieszkującej sporne terytoria, do czego prawdopodobnie przyczyni się Kongres Pokojowy 5 .

Kontrolę nad Wilnem Polacy utracili już po kilku dniach (5 I 1919), kiedy to wojska sowieckie z 2 Brygady Strzelców Dywizji Pskowskiej, wspomagane przez 5 Pułk Wileński, wyparły z Wilna broniące się nieregularne oddziały polskiej samoobrony ${ }^{6}$.

Celem prezentowanego opracowania jest przedstawienie jednego z ważniejszych etapów walk o Wilno, które miały miejsce w początkowym okresie konfliktu polsko-sowieckiego (19-21 IV 1919). Nie były one działaniami rozstrzygającymi o losach tej wojny i przynależności Wilna do II Rzeczypospolitej, były jednak przykładem ówczesnych zdolności planistycznych polskich sztabowców, roli Naczelnego Wodza oraz determinacji bojowych polskich żołnierzy, których brawurowa postawa na polach bitew wojny polsko-sowieckiej często rozstrzygała (podobnie jak w walkach o Wilno) o ich rezultatach.

Na temat walk o Wilno w czasie Świąt Wielkanocnych 1919 r., powstało szereg opracowań i artykułów, ukazało się także kilka wspomnień i analiz autorstwa uczestników wyprawy wileńskiej. O walkach o Wilno i całej „wyprawie wileńskiej” pisali: Juliusz Kaden-Bandrowski', Wacław Lipiński ${ }^{8}$, Tadeusz

5 W. Wielhorski, Polska a Litwa. Stosunki wzajemne w biegu dziejów, Londyn 1947, s. 295. Zdaniem Piłsudskiego istniały różnice poglądów w kwestii uregulowania granic wschodnich Rzeczypospolitej. Marszałek podkreślał: „Ja kładłem nacisk na siłę stworzenia faktów dokonanych. Zwracało wówczas uwagę, że w niektórych częściach dawnej Rosji istnieją fakta dokonane, uskutecznione rozbieżnością tam przedstawicieli wielkich mocarstw. Tak było w Kijowie”. J. PiŁSUdSKI, Pisma zbiorowe. Wybranie prac dotychczas drukiem ogtoszonych, t. 6, oprac. K. Św ITALSKI, Warszawa 1937, s. 122. Inaczej sytuację oceniał Paderewski: „Zdawało mu się, że jeżeli pozyska poparcie Ameryki, która przez Wilsona miała istotnie wpływ na myśl europejską, to rzeczy mogłyby wziąć taki obrót, że udałoby się uzyskać zgodę na stworzenie stanów zjednoczonych wschodniej Europy. Paderewski już nawet dzielił ziemie poza Bugiem na stany”. J. GierowsKa-KaŁŁAur, Odczyt Marszatka Pitsudskiego wygtoszony $w$ dniu 23 sierpnia 1923 roku w Wilnie, „Przegląd Wschodni” 1999, t. 5, z. 4, s. 782-783.

${ }^{6}$ L. Wyszczelski, Wilno..., s. 48, 50. Vide: P. Łossowski, Konflikt polsko-litewski 19181920, Warszawa 1996, s. 32-35.

7 J. KADEN-BANDROwski, Wyprawa wileńska, Warszawa 1919.

8 W. Lipı́́ski, Od Wilna po Dynaburg. (Wspomnienia z ofensywy 5 p.p. Legionów), Warszawa 1930. 
Piskor ${ }^{9}$, Stanisław Szeptycki ${ }^{10}$ czy wreszcie sam Józef Piłsudski ${ }^{11}$. Warto również zwrócić uwagę na opracowania autorstwa Adama Przybylskiego ${ }^{12}$, Bolesława Waligóry ${ }^{13}$, a z czasów nam współczesnych Lecha Wyszczelskiego ${ }^{14}$, Andrzeja Czesława Żaka ${ }^{15}$ czy Aleksandra Smolińskiego ${ }^{16}$ (i inne).

\section{Sytuacja polityczna i militarna na Wileńszczyźnie wiosną 1919 roku}

Naczelne Dowództwo Wojska Polskiego zdawało sobie sprawę z tego, że realizacja polskiej polityki na wschodzie związana jest przede wszystkim z organizacją na tym obszarze sił zbrojnych, zdolnych do obrony interesów narodowych. Bez wątpienia powstające spontanicznie oddziały samoobrony nie były rozwiązaniem wystarczającym. W tej sytuacji podjęto decyzję o uregulowaniu problemu umowy z dowództwem Ober-Ostu, co spowodowało możliwość (umowa w Białymstoku z 5 lutego 1919), przemarszu na Litwę około 10000 żołnierzy Wojska Polskiego i utworzenie frontu przeciw Sowietom ${ }^{17}$. Na przełomie

9 T. PIsкor, Wyprawa wileńska, Warszawa 1919

10 S. Szeptycki, Front Litewsko-Biatoruski. 10 marca 1919 - 30 lipca 1920, Warszawa 2016.

${ }^{11}$ J. PiŁsudski, Pisma zbiorowe Wybranie prac dotychczas drukiem ogtoszonych, t. 5-6, oprac. K. Świtalski; t. 7, oprac. J. Moszczeński, Warszawa 1937.

12 A. Przy bylski, Dziatania wstępne w wojnie polsko-rosyjskiej 1918-1920, Warszawa 1928; IDEM, Ofensywa na Wilno w kwietniu 1919 roku, Warszawa 1929 oraz Wojna polska 1918-1921, Warszawa 1930.

13 B. Waligóra, Walki o Wilno: Okupacja Litwy i Biatorusi w 1918 r. - 1919 r. przez Rosje Sowiecka, Wilno 1938.

${ }^{14}$ L. Wyszczelski, Wilno 1919-1920...; IDEM, Niewypowiedziana wojna. Polsko-rosyjskie dziatania militarne w 1919 roku, Toruń 2005, s. 51-107. Na temat szerszego kontekstu działań militarnych wojny polsko-rosyjskiej 1919-1920 roku (w tym operacji wileńskiej) pisze L. WyszczeLSKI, Wojsko Polskie w latach 1918-1921, Warszawa 2006, s. 300 i n.

15 A.C. Ż̇K, Wilno 1919-1920, Warszawa 1993.

16 A. Smoliński, Jazda Rzeczypospolitej Polskiej w okresie od 12 X 1918 do 25 IX 1920, Toruń 2000, s. 196-206; IDEM, „Wyprawa wileńska” w kwietniu 1919, Szczecin 2020.

17 Vide: A. Przy bylski, Dziatania wstępne..., s. 3-5; B. Waligóra, Walka o Wilno: Okupacja Litwy $i$ Biatorusi..., s. 17-25. W artykule V umowy zapisano: „Przedstawiciele niemieccy upełnomocnieni do zawarcia umowy zapewniają niniejszym, że, marsz polski przeciw bolszewikom, na razie w sile mniej więcej 10 batalionów po najwyżej 800 (ośmiuset) ludzi, dwóch szwadronów i dwóch baterii po 4 działa, będzie się mógł odbyć przez Białystok i dalej przez Grodno i Wołkowysk. Puszczenie w ruch tych transportów może nastąpić w dwa dni po podpisaniu niniejszych umów 
lutego i marca 1919 r. walki miały głównie charakter lokalny, sprowadzały się do prób opanowywania przez wojska polskie węzłów kolejowych i ważniejszych ośrodków administracyjnych.

W rezultacie ustaleń polsko-niemieckich o przepuszczeniu przez polskie terytorium wojsk Ober-Ost z terenów Białorusi, Litwy i Ukrainy, na tych obszarach pojawiły się regularne oddziały W ${ }^{18}$. Dowodzona przez gen. Antoniego Listowskiego Grupa Poleska zajęła Terespol, Brześć i Kobryń, a dowodzona przez gen. Wacława Iwaszkiewicza Dywizja Litewsko-Białoruska (13 lutego 1919) wkroczyła do Wołkowyska. Konsekwencją tych działań był wzrost zagrożenia otwartym konfliktem z Rosjanami. Do pierwszej potyczki z Armią Czerwoną doszło 14 lutego 1919 r.w rejonie Berezy Kartuskiej, gdzie oddziały samoobrony wileńskiej dowodzone przez kpt. Piotra Miernickiego pokonały oddział wojska sowieckie ${ }^{19}$.

Wkraczając na te tereny, Wojsko Polskie sąsiadowało z oddziałami niemieckimi (Ober-Ost) od rejonu Grodna aż po Prypeć. Wojska polskie znajdowały się na zachód od Lidy, na wschód od rzeki Szczary i w Sołonimiu, w rejonie Kanału Ogińskiego, rzeki Jasioły, aż po Pińsk. Od 19 lutego 1919 r. wojska sowieckie utworzyły Front Zachodni, dowodzony przez Dmitrija Nikołajewicza Nadieżnyja (w składzie: 7 Armia Aleksandra Kondratowicza Remiezowa, skierowana na Estonię), ponadto Czerwona Armia Łotewska, dowodzona przez Joachima

przez przedstawiciela niemieckiego dra Bühlmanna i przedstawiciela polskiego doktora Kolankowskiego" - A. Przy bylski, Dziatania wstępne..., s. 12. Na zajmowanych terenach swoją działalność rozpoczęła Dywizja Litewsko-Białoruska, której pierwszym dowódcą został generał Wacław Iwaszkiewicz-Rudoszański. Vide: B. Waligóra, Dzieje 85 putku strzelców wileńskich, Warszawa 1928, s.15-16. O stanie Dywizji Litewsko-Białoruskiej na początku 1919 r., wspominał po latach m.in. gen. Stanisław Szeptycki: „Dywizja znajdowała się w stadium organizacji. Nie była więc kompletna ani liczebnie, ani po względem materiałowym. Wszędzie dawały się odczuwać braki, szczególnie broni i amunicji, płaszczów i obuwia" - S. Szep TyCKi, Front Litewsko-Biatoruski..., s. 15.

${ }^{18}$ Dokumenty i materiaty do historii stosunków polsko-radzieckich, t. 2: Listopad 1918 - kwiecień 1920, oprac. W. Gostyńska, T. Kuźmiński, A. Leinwand, Warszawa 1961, dok. 68, s. 85-90. W ten sposób uzyskano gwarancję, że ani wojska sowieckie, ani Ukraińcy nie opanują tych terenów przed Polakami. Vide: A. Czubiński, Walka Józefa Pitsudskiego o nowy ksztatt polityczny Europy Srodkowo-Wschodniej w latach 1918-1921, Toruń 2002, s. 106.

19 Przez wielu historyków potyczka ta uważana jest z początek wojny polsko-bolszewickiej. Vide: A. Nowak, Polska i trzy Rosje. Studium polityki wschodniej Józefa Pitsudskiego (do kwietnia 1920 roku), Kraków 2002, s. 223-242. Inni za początek wojny uznają datę 4 I 1919 r., co jest związane z wkroczeniem wojsk Armii Czerwonej do Wilna. Vide: J. BORZĘCKI, Kiedy zaczęta się wojna polsko-sowiecka z lat 1919-1920? Rozważania z punktu widzenia polityczno-militarnego, „Dzieje Najnowsze" 2013, R. 45, nr 3, s. 25-37. 
Joachimowicza Wacetisa - z zadaniem okupacji Łotwy i Kurlandii oraz Armia Zachodnia - dowodzona przez Andrieja Jewgienjewicza Sniesariewa - z zadaniem zajęcia Litwy i Białorusi ${ }^{20}$. Na froncie Baranowicze-Lida-Wilno-Orany znajdowały się także oddziały wojsk litewskich ${ }^{21}$.

Zamiary sowieckie były jednoznaczne, już 18 listopada 1918 r. pełniący funkcję przewodniczącego Rewolucyjnej Rady Wojennej Rosji Radzieckiej - Lew Trocki (Lejba Dawidowicz Bronsztejn) - wskazywał za niezbędne połączenie sił z rewolucjonistami w Europie zachodniej, czego konsekwencją miała być ogólnoeuropejska rewolucja ${ }^{22}$. Z kolei w marcu 1919 r. na zjeździe III Międzynarodówki komunistycznej (Kominternu) zakładano dalszy marsz Armii Czerwonej na Zachód Europy i utworzenie Światowej Federacji Republiki Rad ${ }^{23}$.

Zdając sobie sprawę z groźby wybuchu tzw. „światowej rewolucji”, strona polska podjęła działania wyprzedzające. Naczelnik Państwa Józef Piłsudski, tak charakteryzował sytuację:

Postawiłem też sobie, niezależnie od nikogo, już w r. 1918 wyraźny cel dla wojny z Sowietami. Zdecydowałem, mianowicie, natężyć siły, aby możliwie daleko od miejsc, gdzie się nowe życie wykluwało, obalić wszystkie próby narzucania raz jeszcze życia obcego, życia nieurządzonego przez nas samych. W roku 1919 zadania tego dokonałem. Odrzuciłem próby sowieckie tak daleko, że pracy odbudowy własnego życia, takiej złej czy dobrej, w to nie wchodzę, Sowiety nie były w stanie mącić i jej przeszkadzaćé

${ }^{20}$ L. WyszcZelski, Wilno..., s. 66-67.

${ }^{21}$ T. Piskor, Wyprawa wileńska..., s. 7. Przeprowadzony w grudniu 1919 r. przez administrację Zarządu Cywilnego Ziem Wschodnich spis ludności, ograniczony do trzech Okręgów - Wileńskiego, Brzeskiego i Mińskiego - wykazał, że ludność polska dominowała w Okręgu Wileńskim, stanowiąc tam z 1,633 mln mieszkańców - 53,6\% ogółu ludności. Vide: A.J. MielcareK, Węztowe zagadnienia ustrojowe Zarządu Cywilnego Ziem Wschodnich (1919-1920), w świetle aktów normatywnych, „Studia z Dziejów Państwa i Prawa Polskiego” 2011, t. 14, s. 243.

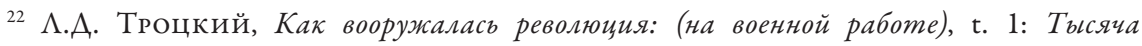
девятьсот восемнадиатый год, Москва 1923, s. 393. Vide: R. Pipes, Rosja bolszewików, Warszawa 2005, s. 188.

23 W. Materski, Na widecie. II Rzeczpospolita wobec Sowietów 1918-1943, Warszawa 2005, s. 41. Już w listopadzie 1918 r. wojska bolszewickie rozpoczęły marsz na Zachód, opanowując do końca roku większą część Litwy i Białorusi oraz częściowo Łotwę i Estonię. A. PrZYBYLSKI, Wojna polska..., s. 57-58.

${ }^{24}$ J. PiŁsudski, Pisma zbiorowe..., t. 7, s. 147. Tadeusz Piskor (Wyprawa wileńska..., s. 6), podkreślał, że według danych wywiadowczych z początkiem maja należało się liczyć z rozpoczęciem działań bolszewickich przeciwko polskim oddziałom. 
Działania polskie miały dwa aspekty: militarny i polityczny. Militarnie były zwrócone przeciw Armii Czerwonej, a politycznie przeciw koncepcjom litewskim, zarówno związanym z celami Litewsko-Białoruskiej Republiki Sowieckiej (co należy łączyć z planami sowieckimi), jak i z pretensjami terytorialnymi Litwy niepodległej ${ }^{25}$. W tym drugim przypadku wynikało to z fiaska działań na rzecz powstania federacji. Kluczem do realizacji idei federacji była jednak Litwa. W polskich koncepcjach federacyjnych Litwa była czynnikiem niezbędnym, warunkiem odbudowania Wielkiego Księstwa Litewskiego z trzema członami: Litwą etniczną, Wileńszczyzną i Białorusią. Dopiero rozwiązanie tego problemu pozwoliłoby wyjść z szerszą inicjatywą wobec Ukrainy, byłoby także zachętą do bliższego związania się sojuszami z Polską dla Łotwy i Estoniii ${ }^{26}$.

Piłsudski zdawał sobie z sprawę z sytuacji międzynarodowej. Rada Najwyższa Sprzymierzonych ostrzegała polskie władze przed podejmowaniem akcji zaczepnych i tworzeniu na kresach wschodnich tzw. „faktów dokonanych”. W lutym 1919 r. w ramach Komisji do Spraw Polskich, kierowanej przez Julesa Cambona powołano tzw. sekcję gen. Henri Le Ronda, która miała przygotować projekt przebiegu granicy na wschodzie Polski ${ }^{27}$. Piłsudski nie mógł liczyć na porozumienie ze zwolennikami białej Rosji, takiego porozumienia również nie szukał. Wnioski były jednoznaczne:

1. Wyczerpana wojną domową Rosja nie będzie mogła przeciwstawić się oderwaniu limitrofów, jeżeli zaistnieje konieczność zmierzenia się z poważniejszymi siłami zbrojnymi; 2. Nie istnieje możliwość porozumienia się ani z Kołczakiem, ani Denikinem, ani też Judeniczem, którzy nawet samą Polskę w granicach etnograficznych skłonni są traktować jako część zagadnienia rosyjskiego - Rosji; 3. Rosja Radziecka będzie mniejszym ztem (ze względu na swą rzekomą słabość) i być może okaże się bardziej skłonna do porozumienia ${ }^{28}$.

25 W. Materski, Na widecie..., s. 42. Litwini obstawali przy tym, że Wilno i okręg wileński należą do Litwy. Premier Augustinas Voldemaras zgłaszał pretensje terytorialne do Suwałk, Grodna, Lidy, Białegostoku, Wołkowyska i Brześcia nad Bugiem. P. Łossowski, Stosunki polsko-litewskie w latach 1918-1930, Warszawa 1966, s. 72.

26 Szerzej: P. OKULEW ICz, Koncepcje „międzymorza” w myśli i praktyce politycznej obozu Józefa Pitsudskiego w latach 1918-1926, Poznań 2001.

27 Sprzymierzeni liczyli na to, że po pokonaniu bolszewików dojdzie do odbudowy mocarstwowej Rosji. Korzystne decyzje na rzecz Polski, dotyczące kształtu granicy wschodniej Rzeczypospolitej, mogły być nie do przyjęcia przez Rosję, sojusznika w ramach Ententy. T. Kom ARNICKI, Pitsudski a polityka wielkich mocarstw zachodnich, Londyn 1952, s. 38-40.

28 Vide: Ibidem, s. 51. 


\section{Plan ofensywy wileńskiej}

Podstawą do podjęcia działań na wschodnich kresach rodzącej się Rzeczypospolitej była chęć kontroli nad Wilnem i Wileńszczyzną. Pod koniec lutego 1919 r. Piłsudski uznał za realne podjęcie działań militarnych. Za możliwością podjęcia takich działań, przemawiały także powodzenia militarne. Ofensywa polska na linii rzeka Szczara-Pińsk, pokazała słaby opór ze strony sowieckiej. Innym argumentem było opanowanie przez oddziały grupy gen. Szeptyckiego przejść przez Niemen w rejonie Skidel-Mosty, co umożliwiało przeprawę wojsk polskich w tym rejonie ${ }^{29}$.

Do przygotowania planu ofensywy na miasto (Wilno) przystąpiono w końcu marca 1919 r. W tajemnicy powołano specjalną grupę sztabową z udziałem m.in.: ppłk. Juliana Stachiewicza (szefa sekcji I z Oddziału I Operacyjnego Sztabu Generalnego), mjr. Tadeusza Kasprzyckiego (Adiutantura Generalna), kpt. Stanisława Nilskiego-Łapińskiego (Sztab Generalny) czy ppłk. Michała Tokarzewskiego-Karaszewicza ${ }^{30}$.

W dniu 26 marca 1919 r. w Brześciu Litewskim odbyło się spotkanie Naczelnika Państwa z dowódcami frontu przeciw Sowietom, gen. Stanisławem Szeptyckim i gen. Antonim Listowskim. Zapadły pierwsze decyzje dotyczące następnych działań. Plan zakładał zdobycie Wilna.

Pierwotny plan zakładał przeprowadzenie zagonu kawaleryjskiego na przestrzeni około $100 \mathrm{~km}$, by trzeciego dnia marszu zaatakować Wilno, bronione przez piechotę. Piechota polska miała dotrzeć do miasta po 24 godzinach, co rodziło groźbę zorganizowania przez przeciwnika pomocy dla walczących w Wilnie wojsk sowieckich ${ }^{31}$. Plan spotkał się z krytyką szefa wojskowej misji francuskiej gen. Paula Prospera Henrysa, który uważał go za szaleństwo ${ }^{32}$.

W Belwederze, 6 kwietnia 1919 r. odbyła się narada, Józef Piłsudski zapoznał członków Komitetu Obrony Kresów z planami dotyczącymi działań na Litwie.

29 A. PrZybylski, Wojna polska..., s. 60.

${ }^{30}$ L. Wyszczelski, Niewypowiedziana wojna..., s. 52. Płk Michał Karaszewicz-Tokarzewski miał zająć się stroną przygotowania organizacji wojska pod względem gospodarczym, J. PIŁSUDSKI, Pisma..., t. 6, s. 107.

31 A. PRZybylski, Wojna polska..., s. 14.

${ }^{32}$ L. Wyszczelski, Niewypowiedziana wojna..., s. 55. 
Według koncepcji Piłsudskiego na Litwie miał powstać rząd narodowy, zakładano także wprowadzenie działań legislacyjnych ${ }^{33}$.

W liście do niezbyt przychylnego dla tych rozwiązań gen. Stanisława Szeptyckiego, datowanym na 7 kwietnia 1919 r., Piłsudski pisał: „Stachiewicz zameldował mi pogląd Generała na prowadzenie zamierzonej operacji na Wilno. Nie mogę jednak odstąpić od zasadniczego swego postanowienia, że operacje te będą się odbywały pod moją osobistą komendą. Uważając Pana za głównego swego pomocnika, zupełnie szczerze i otwarcie wyłuszczę powody tej decyzji”34.

W dalszej części listu Piłsudski tłumaczył znaczenie planowanej operacji wojskowej:

Po pierwsze, w samem Wilnie wiąże się całe mnóstwo zagadnień natury politycznej, które prawdopodobnie od razu na miejscu rozstrzygać będzie potrzeba. (...) Po drugie, w samych operacjach wojennych główne przeszkody, jakie napotkamy, polegają przede wszystkim na prawdopodobnym zmęczeniu żołnierza maszerującego po bardzo ubogim kraju bez dostatecznego zabezpieczenia tyłowych komunikacji, to znaczy, że zarówno oficerowie, jak i żołnierze będą musieli wydobyć ze siebie cały zapas woli i energii dla przezwyciężenia zarówno codziennych drobnych tarć technicznych, jak i własnej słabości. Wobec tego zaś, że cała praca będzie wykonywana przez wojska, których zasadniczym elementem będą dawni legioniści i moi dawni podkomendni, jestem przekonany, że moja obecność i komenda człowieka, do którego się przyzwyczaili i czują gorące przywiązanie, najbardziej wpłynie na zwiększenie szans powodzenia w operacji. Wreszcie trzecie, choć to może jest najmniejszym, operacja ta jest ziszczeniem moich personalnych czysto marzeń i zadowoleniem może największym ze wszystkich zadowoleń, jakie spotkały mnie $\mathrm{w}$ dotychczasowej karierze ${ }^{35}$.

Piłsudski rezygnował z dowodzenia szczeblem strategicznym, kierując się własnymi dążeniami związanymi z zajęciem Wilna, godził się na kierowanie działaniami operacyjnymi.

33 W naradzie obok Józefa Piłsudskiego brali udział m.in.: Michał Römer, Aleksander Prystor, Witold Abramowicz i Kazimierz Świtalski. Na czele rządu polskiego (z udziałem Litwinów) miał stanąć Michał Römer. Vide: J. Ochmański, Kulisy wyprawy wileńskiej Pitsudskiego z 1919 roku, [w:] Zdziejów stosunków polsko-radzieckich. Studia i materiaty, t. 3, red. T. CIEśLA K et al. Warszawa 1968, s. $64 \mathrm{in}$.

${ }^{34}$ A.C. Ż̇ $\mathrm{AK}$, Wilno 1919-1920..., s. 32-33. Vide: List do gen. Szeptyckiego, dowódcy na Litwie i Biatorusi, zawiadamiający go o decyzji objęcia osobiście dowodzenia operacją dla oswobodzenia Wilna io dyspozycjach szczegótowych związanych z tą akcja (7 kwietnia 1919), [w:] Listy Józefa Pitsudskiego, wstęp K. ŚwitalsKi, „Niepodległość” 1962, t. 7, s. 24.

${ }^{35}$ Ibidem, s. 25-26. 
W odpowiedzi na list Naczelnego Wodza, gen. Szeptycki 9 kwietnia 1919 r. sugerował Piłsudskiemu, że dla sprawnego zajęcia Wilna należy przeprowadzić operacje odciążające. Pisał:

Jestem zdania, że operacja na Wilno musi być poprzedzona zajęciem linii okopów niemieckich, idących poza Baranowiczami przez Korelicze, aż do Lubcza nad Niemnem, dalej po Niemnie aż do ujścia Gawii, dalej wzdłuż Gawii do Zemisława, dalej linia Konwaliszki-Werenowo. Ta linia raz zajęta przez nasze wojska, a poprzedzone jej zajęcie pobiciem bolszewików pod Baranowiczami, Nowogródkiem i Lidą - będzie najlepszym zakryciem operacji na Wilno (...). Wobec tego, że ja mam dziś w rękach wszelkie nici dla przeprowadzenia ofensywy Baranowicze-Lida (...) proponuję by Komitet zechciał mnie zostawić przeprowadzenie tej operacji aż do jej uskutecznienia i oddawszy potem ten front generałowi Mokrzyckiemu dopędzenie Komendanta pod Wilnem lub daj Boże we Wilnie ${ }^{36}$.

Propozycje gen. Szeptyckiego w znaczny sposób wydłużałyby okres realizacji ofensywy wileńskiej.

Pierwotny plan zajęcia Wilna uległ pewnym modyfikacjom, na co wpływ miały wiadomości o budowie przez Rosjan umocnień nad Mereczanką i w Puszczy Rudnickiej. Piłsudski zdecydował się zmienić marszrutę kawalerii (zmiana osi działania), kierując ją na trakt biegnący wzdłuż linii kolejowej Lida-Wilno. Kawalerzyści mieli wejść na wspomniany trakt przez Myto, Krupę i Żyrmuny, obchodząc Lidę od zachodu i północy. Tą samą drogą miała podążyć grupa piechoty. Piłsudski wzmocnił także oddziały gen. Szeptyckiego, dodając oddział mjr. Dąbrowskiego z grupy gen. Listowskiego, który miał uczestniczyć w natarciu na Baranowicze ${ }^{37}$.

${ }^{36}$ Ibidem, s. 27-28. Odpowiedź gen. Stanisława Szeptyckiego na list Piłsudskiego. Wołkowyska- 9 IV $1919 \mathrm{r}$.

3710 IV 1919 r. - wydano stosowny Rozkaz Nacz. Dow. WP Nr 7124/ I - w sprawie organizacji grupy kawaleryjskiej. Vide: T. PISkor, Wyprawa..., s. 8-9 oraz rozkazy NDWP z 10 IV 1919 r. - do gen. Szeptyckiego, 11 IV 1919 r. - do gen. Rydza-Śmigłego. Vide: A. Przy bylski, Ofensywa na Wilno..., s. 20-23. 


\section{Sytuacja militarna na terenach objętych planem ofensywy wileńskiej}

Przygotowując plany wyprawy wileńskiej, Naczelny Wódz dokonał podziału sił w niej uczestniczących. Sztab Piłsudskiego miał się znajdować w miejscowości Szydłowiec. Grupy uderzeniowe na Wilno znalazły się pod jego osobistym dowództwem. Z kolei za organizację pozostałych oddziałów odpowiadał gen. Stanisław Szeptycki.

15 kwietnia w kwaterze Piłsudskiego w Skrzybowcach odbyła się ostatnia odprawa. Obok Piłsudskiego uczestniczyli w niej: gen. Stanisław Szeptycki, gen. Rydz-Śmigły, ppłk Władysław Belina-Prażmowski, ppłk Julian Stachiewicz, mjr Tadeusz Piskor i mjr Tadeusz Kasprzycki ${ }^{38}$. Józef Piłsudski ustalił ostateczny plan działania. Całe przedsięwzięcie miało dwa kierunki:

1. Opanowanie Wilna,

2. Zabezpieczenie tyłów.

Do działań wyznaczono: większość sił gen. Antoniego Listowskiego pod Łunińcem, prawe skrzydło wojsk gen. Stanisława Szeptyckiego, dowodzone przez gen. Stefana Mokrzeckiego (tzw. „front rzeki Szczary”) oraz część sił Grupy Operacyjnej gen. Antoniego Listowskiego (zgrupowanie mjr. Władysława Dąbrowskiego) pod Baranowiczami i Nowogródkiem. W działaniach na Lidę miało brać udział zgrupowanie gen. Józefa Lasockiego (w składzie: trzy bataliony, jedna bateria artylerii polowej, dwie baterie artylerii ciężkiej z 1 Dywizji Piechoty Legionów, dowodzonej przez gen. Bolesława Roję) oraz dwa bataliony piechoty z 1 Suwalskiego Pułku Strzelców i jedna bateria artylerii (zgrupowaniem dowodził mjr Mieczysław Mackiewicz) i Grupy Jazdy mjr. Janusza Głuchowskiego (dwa i pół szwadronu), a także Grupa Zaniemeńska płk. Stanisława Rawicza-Dziewulskiego - stanowiąca osłonę od strony Grodna.

W skład Grupy rajdowej przeznaczonej do zajęcia Wilna wchodziły: Grupa kawaleryjska (1 Brygada Jazdy) pod dowództwem ppłk. Władysława Beliny-Prażmowskiego oraz oddziały 2 Dywizji Piechoty Legionów gen. Edwarda Rydza-Śmigłego dla zajęcia Wilna ${ }^{39}$. Do planowanej operacji łącznie wydzielono:

38 G. Łukomski, B. Pola , M. Wrzosek, Wojna polsko-bolszewicka 1919-1920, t. 1: 1 stycznia 1919-29 lutego 1920, red. B. Pola K, Koszalin 1990, s. 75.

39 L. Wyszczelski, Niewypowiedziana..., s. 57-58. 
dwadzieścia jeden i pół batalionu piechoty, dwadzieścia cztery szwadrony jazdy, dziewięć baterii artylerii polowej, dwie baterie artylerii ciężkiej i pół baterii artylerii konnej ${ }^{40}$.

Po stronie bolszewickiej na tym obszarze działały oddziały wchodzące w skład Frontu Zachodniego. Miały one za zadanie utrzymanie dwóch linii obronnych od Dźwina do Dyneburga-Mołodeczna-Mińska-BobrujskaŻłobia-Homla oraz linii wysuniętej: Tukum-Libawa-Szawle-PoniewieżWilno-Lida-Baranowicze-Euniniec ${ }^{41}$.

W przypadku zgrupowania wileńskiego w skład sił sowieckich znajdujących się w Wilnie i jego okolicach wchodziły: 1 Brygada z Dywizji Litewskiej oraz 1 Brygada Dywizji Zachodniej wraz ze sztabem. Zgrupowanie liczyło ok. 7000 bagnetów, 120 szabel i 10 dzial ${ }^{42}$. Na południe od zgrupowania wileńskiego znajdowała się Dywizja Zachodnia, działająca od Marcinkaniec aż do jeziora Wygonowskiego, na południe do Baranowicz. Sztab dywizji znajdował się w Mińsku.

Obszar działania podzielono na dwa odcinki: pierwsze zgrupowanie ze sztabem 3 Brygady w Lidzie (w składzie: 3 Pułk Siedlecki oraz bataliony 4 Warszawskiego i 6 Grodzieńskiego Pułków Piechoty, szwadronu huzarów i baterii artylerii); drugie zgrupowanie - ze sztabem 2 Brygady, działające w rejonie Baranowicz (w składzie: 8 Pułk Miński, dwa bataliony 4 Pułku Warszawskiego, batalion 6 Pułku Grodzieńskiego, dwa bataliony łotewskie, oddział marynarzy, dywizjon jazdy i kilku dział). Z kolei w rejonie Nowogródka jeden batalion z 4 Pułku Warszawskiego. Dywizja Zachodnia dysponowała około 6000 bagnetami, 250 szablami i 12 działami ${ }^{43}$. Zadaniem Dywizji Zachodniej było utrzymanie linii Lida-Baranowicze oraz w miarę możliwości wysunięcie straży przednich na linie: Wołkowysk-Grodno i na Brześć nad Bugiem. Poza działaniami wojsk polskich planowanymi w ofensywie wileńskiej, znajdowała się 17 Dywizja Strzelców ze sztabem w Bobrujsku, zgrupowanie dzieliło się

${ }^{40}$ Ibidem, s. 57. Autor zauważa, że większoosć pododdziałów miała niższe stany liczebne od etatowych.

41 A. PrZybylski, Ofensywa na Wilno..., s. 9.

42 Ibidem, s. 11. Zadaniem zgrupowania wileńskiego było: 1. Umocnienie się na linii (pierwsza linia): Zośle-Wysoki Dwór-Hanuszyszki-Przełaje-Marcinkańce oraz (druga linia): Wieprzejezioro Nowotrockie-Orany; 2. Przy wycofywaniu się wojsk niemieckich, bolszewicy mieli wysunąć straże w kierunku: Tylża-Kowno, Olitia-Merecz.

${ }^{43}$ Ibidem. 


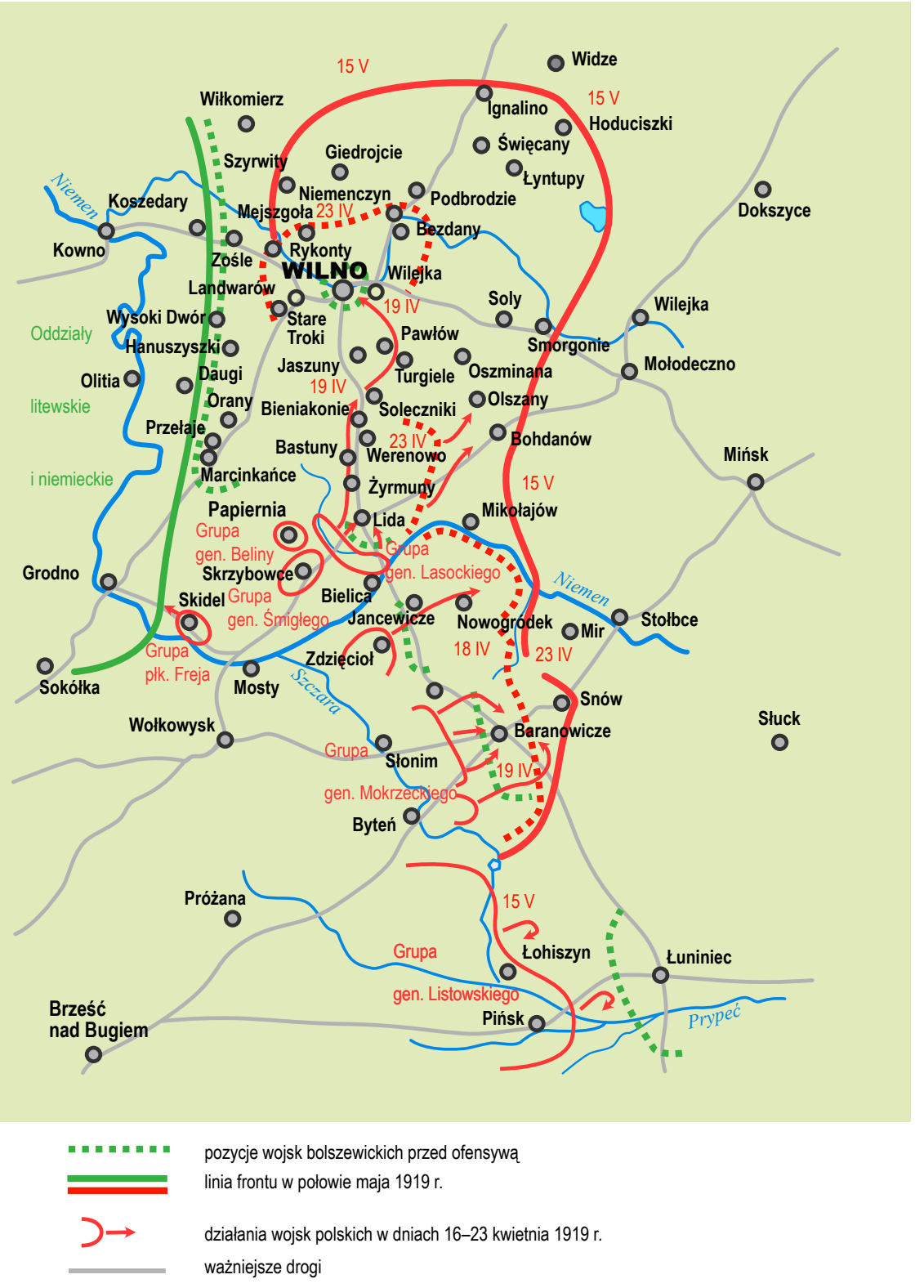

Ryc. 1. Ofensywa na Wilno

(źródło: A. PRZYBYLSKI, Wojna polska 1918-1921, Warszawa 1930, mapy - szkic nr 8) 
na dwie grupy: zlokalizowane w rejonach Łunińca i drugie na północny-wschód od miejscowości Sarny. 17 Dywizja Strzelców liczyła 6000 bagnetów, 150 szabel i 12 dzial $^{44}$.

W Wielką Sobotę 16 kwietnia 1919 r. rozpoczęto walki w ramach wyprawy wileńskiej ${ }^{45}$. Koncepcja ataku na Lidę opierała się na uderzeniu koncentrycznym (od północy, zachodu i południa). Pomimo oporu Rosjan, dzięki wsparciu dwóch batalionów 2 Dywizji Piechoty Legionów miasto zostało zajęte.

Pomimo problemów w walkach o Nowogródek i Baranowicze, Piłsudski zdawał sobie sprawę, że głównym zadaniem oddziałów gen. Mokrzeckiego było związanie stojących przed nim sił nieprzyjacielskich. Uwikłani w walkach Rosjanie nie byli w stanie odzyskać swobody działania, na północ z pomocą Lidzie oraz w kierunku Słonim, by zagrozić naszym tyłom, a tym bardziej zagrozić manewru na Wilno.

\section{Walki o miasto i w mieście Wilno}

Układ sił w rejonie Wilna wskazywał na przewagę Rosjan (Tabela 1). Szybkość działań wojskom polskim miały zapewnić oddziały kawaleryjskie. Sam plan był trudny do wykonania. Elementami, które mogły prowadzić do załamania koncepcji zajęcia Wilna mógł być - po pierwsze - brak łączności (co było widoczne podczas działań 1 Brygady Jazdy), nie tylko pomiędzy poszczególnymi oddziałami, ale co gorsze z Naczelnym Wodzem ${ }^{46}$, a po drugie opóźnienia związane ze stanem dróg, szczególnie oddziałów piechoty.

Zgodnie z wcześniejszymi planami - 18 kwietnia 1919 r. - ppłk Belina-Prażmowski wysłał drugi szwadron 1 Pułku Szwoleżerów w kierunku północnym, z zadaniem przerwania toru kolejowego Wilno-Mińsk w celu uniemożliwienia Sowietom transportu posiłków, ewakuacji Wilna i znajdujących się tam zapasów oraz taboru kolejowego ${ }^{47}$. Grupa kawalerii (1 Brygada Jazdy) wymaszerowała z rejonu Pawłów-Turgiele o godzinie $2.00 \mathrm{w}$ dniu 19 kwietnia w kierunku lasu Dubniaki, skąd 19 kwietnia o godzinie 3:30 rozpoczęła natarcie na Wilno ${ }^{48}$.

\footnotetext{
${ }^{44}$ Ibidem, s. 12.

45 Vide: szczegółowy plan działania operacji wileńskiej. A. PrZy by LSKi, Ofensywa na Wilno..., s. $28-29$

46 O sytuacji związanej z decyzją o wstrzymaniu marszu na Wilno - vide: ibidem, s. 46.

47 A. SMOLiński, „Wyprawa wileńska”..., s. 17.

${ }^{48}$ Opis walk w Wilnie na podstawie T. Piskor, Wyprawa wileńska..., s. 25-46.
} 
Tabela 1

Ordre de Bataille walczących stron o Wilno

\begin{tabular}{|c|c|c|c|c|c|}
\hline \multicolumn{3}{|c|}{$\begin{array}{c}\text { Wojsko polskie } \\
\text { (tzw. grupa rajdowa) }\end{array}$} & \multicolumn{3}{|c|}{$\begin{array}{c}\text { Wojska rosyjskie } \\
\text { (zgrupowanie wileńskie) }\end{array}$} \\
\hline $\begin{array}{c}\text { Nazwa } \\
\text { ugrupo- } \\
\text { wania }\end{array}$ & Dowódca & Sklad grupy & $\begin{array}{c}\text { Nazwa } \\
\text { ugrupo- } \\
\text { wania }\end{array}$ & Dowódca & $\begin{array}{l}\text { Skład } \\
\text { grupy }\end{array}$ \\
\hline $\begin{array}{l}\text { Samo- } \\
\text { dzielna } \\
\text { grupa } \\
\text { kawalerii } \\
\text { (1 Brygada } \\
\text { Jazdy) }\end{array}$ & $\begin{array}{l}\text { Ppłk } \\
\text { Władysław } \\
\text { Belina- } \\
\text {-Prażmowski }\end{array}$ & $\begin{array}{l}1 \text { i } 3 \text { szwadrony } 11 \text { Pułku } \\
\text { Ułanów (mjr Mariusz Za- } \\
\text { ruski); } 3 \text { szwadron } 1 \text { Pułku } \\
\text { Szwoleżerów (mjr Gustaw } \\
\text { Orlicz-Dreszer); szwadron ku- } \\
\text { jawski i } 5 \text { szwadron z } 7 \text { Pułku } \\
\text { Ułanów; } 2 \text { i } 4 \text { szwadrony } \\
4 \text { Pułku Ułanów; szwadron } \\
\text { techniczny } 7 \text { Pułku Ułanów; } \\
\text { pluton artylerii konnej; } \\
\text { pociąg prowiantowy }\end{array}$ & $\begin{array}{l}\text { W mieście } \\
\text { Wilno: }\end{array}$ & $\begin{array}{l}\text { Michaił } \\
\text { Wilgielmo- } \\
\text { wicz Maku- } \\
\text { towicz } \\
\text { Roman } \\
\text { Wojciecho- } \\
\text { wicz Łągwa }\end{array}$ & $\begin{array}{l}1 \text { BS } \\
\text { z Dywizji } \\
\text { Litewskiej } \\
1 \text { BS } \\
\text { z Dywizji } \\
\text { Zachodniej } \\
\text { i sztab do- } \\
\text { wództwa }\end{array}$ \\
\hline $\begin{array}{l}\text { Grupa } \\
\text { piechoty }\end{array}$ & $\begin{array}{l}\text { Gen. } \\
\text { Edward } \\
\text { Rydz-Śmigły }\end{array}$ & $\begin{array}{l}\text { 1, } 2 \text { i } 3 \text { bataliony } 1 \text { Pułku } \\
\text { Piechoty Leg.; } 1 \text { i } 3 \text { Bataliony } \\
5 \text { Pułku Piechoty Leg.; } 1 \text { Bata- } \\
\text { lion } 6 \text { Putku Piechoty Leg.; } \\
2 \text { baterie artylerii }\end{array}$ & $\begin{array}{l}\text { Na zachód } \\
\text { od Wilna: }\end{array}$ & & $\begin{array}{l}2 \text { i } 3 \text { BS } \\
\text { z Dywizji } \\
\text { Zachod- } \\
\text { niej }\end{array}$ \\
\hline Ogółem & \multicolumn{2}{|c|}{$\begin{array}{l}\text { Kawaleria - stan bojowy: } \\
53 \text { oficerów, } 789 \text { szabel, } 9 \text { karabinów maszy- } \\
\text { nowych, } 2 \text { działa, } 951 \text { koni wierzchnich } \\
\text { i } 248 \text { taborowych } \\
\text { Piechota - stan bojowy: } \\
\text { ponad } 4000 \text { bagnetów i dwie baterie artylerii }\end{array}$} & \multicolumn{3}{|c|}{7000 bagnetów, 120 szabel i 10 dział } \\
\hline
\end{tabular}

Źródło: oprac. własne na podstawie T. PIsKOR, Wyprawa wileńska, Warszawa 1919, s. 9-13.

W przypadku walk o Wilno warto zwrócić uwagę na kilka istotnych elementów związanych z przebiegiem działań militarnych. Pierwszym elementem był czynnik zaskoczenia.

Rosjanie nie spodziewali się polskiego natarcia, o czym świadczy fakt braku wojsk bolszewickich na rogatkach miasta. Szwadrony 11 Pułku Ułanów oraz 5 szwadron 7 Pułku Ułanów zajęły wileński dworzec kolejowy (vide: załącznik 
nr 1). Zdobyto liczny tabor kolejowy, wzięto jeńnów ${ }^{49}$. Z kolei po zajęciu dworca kolejowego ułani z 4 Pułku Ułanów sformowali pociąg, który został wysłany po piechotę z grupy gen. Edwarda Rydza-Śmigłego. Ppłk Belina-Prażmowski podjął decyzję do stworzenia obrony przed ewentualnymi atakami nieprzyjaciela z zachodu (od strony Trok i Landwarowa), dla zabezpieczenia dworca kolejowego oraz ewentualnego kierunku odwrotu na Rudomino i Pawłów ${ }^{50}$.

W głąb Wilna udały się dwie grupy jazdy, pierwsza - w sile 1 szwadronu 1 Pułku Szwoleżerów pod dowództwem mjr. Gustawa Orlicz-Dreszera - dotarła w okolice wileńskiej Katedry, a następnie zaułku św. Jerskiego, gdzie znajdował się sztab wojsk sowieckich, druga - pod dowództwem mjr. Mariusza Zaruskiego (1 i 3 szwadrony 11 Pułku Ułanów), nacierająca w kierunku ul. Trockiej i Niemieckiej, dotarła w pobliże klasztoru Wizytek.

Rosjanie stawili silny opór, zatrzymując natarcie oddziału mjr. Orlicz-Dreszera na placu Katedralnym. Po zajęciu pozycji przy ul. Wielkiej mały oddział kawalerzystów (por. Ludwika Kmicic-Skrzyńskiego) starał się zdobyć przeprawę przez Wilię (Zielony Most), odcinając drogę odwrotu nieprzyjacielowi. Po silnym ostrzale ze strony nieprzyjaciela został jednak zatrzymany. Podjęto decyzje o wysłaniu niewielkich patroli, jeden z nich zajął Górę Zamkową, zdobywając 2 karabiny maszynowe, z których ostrzeliwał pozycje sowieckie. Z kolei pluton techniczny zajął koszary pod Górą 51 .

Element zaskoczenia wywołał chaos w działaniach Rosjan. Wojska sowieckie po zorientowaniu się w ilości polskich oddziałów i własnej reorganizacji, nieskutecznie zaatakowały w kierunku Góry Zamkowej. Sowieci stawiali opór w trzech miejscach miasta w okolicach placu Katedralnego, na Łukiszkach i Pohulance. Starali się również utrzymać przeprawy przez Wilię - mosty: Zielony i Zwierzyniecki.

Z kolei szwoleżerowie mjr. Orlicz-Dreszera po przyciągnięciu działa, opanowali okolice placu Katedralnego, z dalszym zamiarem wyparcia nieprzyjaciela

\footnotetext{
$49 \mathrm{Na}$ zajętym dworcu kolejowym zdobyto 13 parowozów, 440 wagonów towarowych, 2 składy pasażerskie (około 30 wagonów). Jeden z transportów przewoził pociski artyleryjskie, w 19 wagonach przewożono żelazo, a w 5 wagonach znajdowała się żywność - A. SMOLIŃski, „Wyprawa wileńska”..., s. 22, przyp. 6.

${ }^{50}$ Szwadrony 4 Pułku Ułanów pod dowództwem rtm. Nowickiego oraz 5 szwadron 7 Pułku Ułanów broniły dworca kolejowego i zabezpieczały kierunek odwrotu. Vide: T. Piskor, Wyprawa..., s. 29.

${ }^{51}$ Vide: P. Wlezień, Wilno - walki w mieście 19-21 kwiecień 1919, http://phw.org.pl/wilnowalki-w-miecie-19-21-kwiecie-1919 (dostęp: 11 X 2020).
} 
za rzekę. Rosjanie stawiali jednak coraz silniejszy opór. Dopiero wieczorny atak jazdy mjr. Orlicz-Dreszera zepchnął część wojsk bolszewickich na północną stronę Wilii.

Drugim istotnym elementem mającym wpływ na przebieg walk były trudności związane z kontrolą nad miastem, która ze względu na ograniczoną ilość żołnierzy była niezwykle uciążliwa dla kawalerzystów ppłk. Beliny-Prażmowskiego.

Szef sztabu Grupy wileńskiej mjr Tadeusz Piskor, charakteryzując walki w mieście, napisał po latach:

Wilno jest miastem, rozrzuconym na dużej przestrzeni, o charakterze miast starych z licznymi zaułkami i krętymi uliczkami, dlatego opanowanie go jest trudne i pochłonąć musi dużo ludzi. Na każdym skrzyżowaniu ulic, na placach, przy ważnych obiektach (dworce, szpitale, kasa, urzędy i.t.d) trzeba było ustalić warty i łączników; atak rozwijał się od razu wszystkim równolegle biegnącymi ulicami. Dużo żołnierzy użytych było do rewizji w lokalach i mieszkaniach, do służby ordynansowej, do eskort, wreszcie przy koniach pozostała czwarta część żołnierzy w charakterze konowodów (...). W skutek tego grupy atakowe mjr. Zaruskiego i [mjr.] Dreszera liczyły zaledwie po kilkudziesięciu ludzi i stale, w miarę posuwania się naprzód, siły ich redukowały się ${ }^{52}$.

W pierwszym etapie walk problemem był także brak amunicji do karabinów maszynowych i karabinków austriackich, które były na wyposażeniu oddziałów polskiej kawalerii. Żołnierze zaczęli sięgać po zdobytą na nieprzyjacielu broń rosyjską.

Zmiana sytuacji nastąpiła wraz ze wzmocnieniem polskich oddziałów. W godzinach wieczornych (około godziny 20:00) do Wilna dojechał transport kolejowy: 3 batalion 1 Pułku Piechoty Legionów, pod dowództwem kpt. Władysława Złom-Langera, wzmacniając obsadę dworca kolejowego. W tej sytuacji szwadrony 4 i 7 Pułku Ułanów przeszły do rezerwy 1 Brygady Jazdy. Z kolei odziały 10 kompanii dołączyły do ułanów mjr. Zaruskiego, a 9 kompanii do szwoleżerów mjr. Orlicz-Dreszera. Jedna kompania stanowiła odwód do wykorzystania w przypadku zagrożenia polskich oddziałów ${ }^{53}$.

Trzecim istotnym elementem widocznym podczas prowadzenia walk, było wsparcie strony polskiej przez ludności miasta.

\footnotetext{
52 T. PIsKor, Wyprawa..., s. 31-33.

53 W. WLEZIEŃ, op. cit.
} 
Entuzjazm ludności polskiej (pisał Tadeusz Piskor - dop. A.W.) wzrastał z godziny na godzinę. Wyrażał się on praktycznie w czynnej pomocy, której udzielali nam w walce dorośli, starcy i dzieci, ostrzeliwując zawzięcie stanowiska karabinów maszynowych bolszewickich i ich skupiska, oraz wykrywając stanowiska bolszewickie. Kobiety uwijały się między walczącymi ułanami, obdarowując ich jadłem, mlekiem, herbatą. Podziwiać należy odwagę ludności cywilnej, która bez bojaźni przed kulami niosła pomoc żołnierzowi polskiemu, czy to walczącemu, czy rannemu. Ludność też przeważnie była dobrym źródłem wiadomości o nieprzyjacielu w samym mieście i okolicy ${ }^{54}$.

Nie wszyscy przyjmowali obecność wojsk polskich z entuzjazmem. „Ludność żydowska (pisał Piskor - dop. A.W.) strzelała do Polaków z okien”55. W sytuacji braku rezerw zaczęto zbroić polską ludność cywilną, robotników ze Stowarzyszenia Św. Kazimierza (kilkaset osób).

W dniu 20 kwietnia od godzin porannych rozpoczęli działania żołnierze 9 i 10 kompanii. Pierwsza z nich - 9 kompania - odparła ataki Rosjan na Górę Zamkową, a następnie przeszła do ofensywy, zajmując ul. Dąbrowskiego i Orzeszkowej. Natarcie wojsk polskich - w kierunku mostu Zwierzynieckiego - spowodowało wycofanie się Rosjan w kierunku Łukiszek.

Z kolei 10 kompania (prawe skrzydło) atakowała wzdłuż ul. Jezuickiej, św. Ignacego i Niemieckiej, opanowując hotel „Pensjon”. W godzinach popołudniowych lewe skrzydło 10 kompanii nacierało w kierunku ul. Mała Pohulanka, zajmując pozycje w al. Róż. Natarcia wojsk polskich nie przyniosły jednak ostatecznych rozstrzygnięć. Z kolei ataki rosyjskie miały bezładny, chaotyczny charakter. Wykorzystując tę sytuację, w godzinach wieczornych mjr Orlicz-Dreszer na czele kilku szwoleżerów i piechurów zaatakował Rosjan przez Zielony Most, przedostając się na druga stronę rzeki. Silny opór Rosjan zmusił atakujących do wycofania się, a mjr Orlicz-Dreszer, odcięty od własnych żołnierzy, ratował się ucieczką wpław przez Wilię ${ }^{56}$.

${ }_{44}$ T. Piskor, Wyprawa..., s. 31.Jak pisał Wacław Lipiński: „Przez miasto przeleciał, niby wicher radosny głos. Poroztwierały się na oścież z trzaskiem drzwi i okna i, wpośród huku i gwałtu karabinowego ognia, w polotach, w radosnych świstach kul, w walce o miasto, przeszła błyskawicą wieść z krańca na kraniec, z domu do domu, wieść niewiarogodna, wieść oszałamiająca, wieść jak z bajki przecudownej - że polscy żołnierze biją się o Wilno". W. Lipı́́ski, Od Wilna..., s. 1-2.

${ }_{55}$ Meldunek Grupy kawaleryjskiej ppłk Beliny. Przedmieścia Wilna z 19 IV 1919 r. g. 6 w. do Generała Edwarda Śmigłego-Rydza Dowódcy 2 dywizji Piechoty (L. op. 239/9). T. PISkor, $W y$ prawa..., s. 36.

${ }^{56}$ A. SMoliński, „Wyprawa wileńska”..., s. 35. 
W godzinach wieczornych i porannych 20/21 kwietnia do miasta dotarły pozostałe oddziały 2 Dywizji Piechoty Legionów, poza batalionem z 6 Pułku Piechoty, który osłaniał na południe od Wilna linię kolejową Werenowo-Wilno. Na wieść o dotarciu oddziałów polskiej piechoty Rosjanie rozpoczęli ewakuację urzędów do Mejszgoły ${ }^{57}$.

Rankiem 21 kwietnia, przystąpiono do działań rozstrzygających w walce o Wilno. Żołnierze 9 kompanii obsadzili brzeg rzeki Wilii i Zielony Most. Również w kierunku rzeki prowadzone były działa 11 kompanii zajmując pozycje wzdłuż ul. Dąbrowskiej, Mickiewicza i Garncarskiej, oraz 10 kompanii na ul. Teatralnej i Raduńskiej (podnóże Góry Bouffałowej). O ile 9, 10 i 11 kompanie miały wiązać siły nieprzyjaciela, to 5 i 6 kompanie, po obejściu Góry Bouffałowej, miały nacierać w kierunku mostu Zwierzynieckiego. Zadaniem 12 kompanii był atak na Łukiszki (przez cmentarz ewangelicki), a 8 kompanii zajęcie dzielnicy Zakręt i organizacja ubezpieczenia od zachodu.

Najcięższe walki toczyły się w rejonach placu Łukiszki i Zielonego Mostu. Skierowanie w ten rejon przez gen. Edwarda Rydza-Śmigłego 1 i 2 kompanii oraz 1 kompanii c.k.m. z 1 batalionu 1 Pułku Piechoty Legionów, spowodowało opanowanie sytuacji i zajęcie dzielnicy Zwierzyniec. Prowadzono także atak wzdłuż brzegu rzeki (11 kompania) w kierunku Śnipiszek. W efekcie natarcia wojsk polskich Rosjanie wycofali się z miasta.

Straty przeciwnika szacuje się na 1800 żołnierzy wziętych do niewoli. Brak danych o zabitych i rannych. Zdobyto cenny tabor kolejowy, magazyny żywności i mundurów, trzydzieści karabinów maszynowych, dużą ilość karabinów ręcznych i amunicji. Podobnie trudne do odtworzenia są straty polskie, szczególnie dotyczy to kawalerii. Wiadomo o stratach w 1 Pułku Piechoty Legionów - dwudziestu dwóch zabitych, pięćdziesięciu sześciu rannych (w tym trzech oficerów) i pięciu zaginionych ${ }^{58}$.

57 Wraz z urzędami wywieziono środki finansowe. T. Piskor podaje, że było to $30 \mathrm{mln}$ rubli, w tym znaczna część w złocie. T. Piskor, Wyprawa..., s. 40.

${ }^{58}$ L. Wyszczelski, Wilno..., s. 124. 


\section{Piłsudski o przynależności Wilna}

Ważnym czynnikiem wpływającym na podjęcie decyzji o wyprawie wileńskiej był sam stosunek Naczelnego Wodza do przynależności Wilna i Wileńszczyzny. Podczas odczytu wygłoszonego 24 sierpnia 1923 r. w Wilnie, Piłsudski podkreślał: „Sprawa wileńska w znaczeniu politycznym otwarta została przez mnie w kwietniu 1919 r., gdym posiadał Wilno jako Naczelny Wódz. Wilno zostało zdobyte orężem"59.

W Odezwie do mieszkańców Wielkiego Księstwa Litewskiego (z 22 IV 1919), po zajęciu Wilna, Piłsudski ogłosił m.in.:

Wojsko polskie, które ze sobą przyprowadziłem dla wyrzucenia gwałtu i przemocy, dla zniesienia rządów krajem wbrew woli ludności - wojsko to niesie wam wszystkim wolność i swobodę. Chcę dać wam możność rozwiązania spraw wewnętrznych, narodowościowych i wyznaniowych tak, jak sami sobie życzyć będziecie, bez jakiegokolwiek gwałtu lub nacisku ze strony Polski. Dlatego to, pomimo, że na waszej ziemi grzmią jeszcze działa i krew się leje, nie wprowadzam zarządu wojskowego, lecz cywilny, do którego powoływać będę ludzi miejscowych, synów tej ziemi ${ }^{60}$.

Wkroczenie do Wilna wojska polskiego oznaczało nie tylko kryzys, ale wręcz upadek koncepcji federacji. Piłsudski miał wątpliwości, jaka będzie dalsza reakcja mieszkańców miasta. W liście do Paderewskiego z 4 maja 1919 r. pisał: „Wobec tego, że Wilno samo znalazłem opuszczone zarówno przez Polaków, jak i przez Litwinów i Białorusinów, nie mogłem utworzyć czegokolwiek szerszego po zajęciu Wilna. I Polacy, i Litwini, i Białorusini przy pertraktacjach z nimi oglądali się jedni na Warszawę, drudzy na Kowno lub Mińsk, gdzie wyemigrowała większość ich przedstawicieli. Do żadnej decyzji nie mogłem ich doprowadzičn'

Podobną opinię dotycząc sytuacji w Wilnie wyraził Naczelny Wódz w liście do gen. Stanisława Szeptyckiego, Piłsudski zauważył:

Wobec ogólnego, tzn. Polaków, Litwinów, Białorusinów, Niemców i Ententy niezdecydowania postanowiłem i ja czekać chwili, kiedy z pomocą większej siły można

59 J. PiŁsudski, Pisma zbiorowe..., t. 6, s. 122. Vide: J. Gierowska-Kaleaur, Odczyt Marszatka Pitsudskiego..., s. 781.

${ }^{60}$ IDEM, Pisma zbiorowe..., t. 5, s. 75.

${ }^{61}$ Ibidem, s. 83. 
będzie jeszcze raz przełamać sytuację na naszą korzyść. Do tego czasu unikam ostatecznego wypowiedzenia się i na równo $z$ innymi odwlekam decyzje... ${ }^{62}$

Wyprawa wileńska z kwietnia 1919 r. była początkiem gry o Wilno. W tej kwestii Piłsudski miał wielu przeciwników politycznych nie tylko w Polsce (doszło do kryzysu parlamentarnego), ale i na arenie międzynarodowej, nie tylko Litwinów, Anglików, ale całą Ententę.

\section{Zakończenie}

Ofensywa wileńska była pierwszą polską operacją zbrojną w wojnie z Sowietami. Jej istotny element stanowiły walki w samym mieście. Wysoko należy ocenić prowadzenie działań militarnych przez ppłk. Władysława Belinę-Prażmowskiego ${ }^{63}$, kpt. Władysława Złom-Langnera ${ }^{64}$ czy mjr. Gustawa Orlicz-Dreszera $^{65}$. Ofensywa wileńska, a szczególnie walki o Wilno w dniu 19 kwietnia 1919 r., była operacją głównie kawaleryjską ${ }^{66}$.

${ }^{62}$ List J. Pitsudskiego do S. Szeptyckiego z 4 V 1919 r., [w:] W. STAnkiew ICz, Sześć listów Józefa Pitsudskiego do Stanistawa Szeptyckiego z okresu wojny polsko-radzieckiej, „Dzieje Najnowsze” 1971, nr 3, s. 158.

${ }^{63}$ Władysław Belina-Prażmowski m.in. za dowodzenie Grupą Kawalerii (1 Brygada Jazdy) w walkach o Wilno otrzymał order Virtuti Militari V klasy. Vide: J.M. Majchrowski, Pierwsza Kompania Kadrowa. Portret oddziatu, Kraków 2002, s. 61. W dniu 7 V 1919 r. został awansowany na stopień pułkownika z dniem 1 V 1919 r. Vide: „Dziennik Rozkazów Wojskowych”, nr 57 z 24 V 1919 r., poz. 1803.

${ }^{64}$ Władysław Złom-Langner za udział w walkach o Wilno od 19 IV 1919 r., a szczególnie walkę w mieście i jego zdobycie 21 IV 1919 r., otrzymał order Virtuti Militari V klasy (nr 2711). Vide: G. Łuкomski, Langner Wtadystaw, [w:] Kawalerowie Virtuti Militari 1792-1945, t. 2: (19141945), cz.1, Koszalin 1991, s. 85-86.

${ }^{65}$ Vide: A. Wojtaszak, Generalicja Wojska Polskiego 1918-1926, Warszawa 2012, s. 601-603 (biogram Gustawa Orlicza-Dreszera).

${ }^{66}$ Niewątpliwie pierwszym znaczącym wydarzeniem było zajęcie Wilna 19 IV 1919 r. przez wojska polskie. Prawo do posiadania tego miasta rościły sobie trzy narody: Litwini, Białorusini i Polacy. Każdy z nich miał swoje argumenty, a Piłsudski - dodatkowo motywy osobiste: było to jego miasto rodzinne. Siłowe rozwiązanie kwestii Wilna zamknęło Warszawie drogę do współpracy z polityczną elitą litewską i białoruską, bez czego problematyczne stawało się utworzenie w przyszłości państwa litewsko-białoruskiego, będącego sojusznikiem Polski. A. SMolıński, „Wyprawa wileńska"..., s. 42 . 
Jakie doświadczenia dała wyprawa wileńska i sama walka o Wilno? Bezsprzecznie, polska sztuka wojenna została wzbogacona o umiejętności ${ }^{67}$ :

- organizacji działań rajdowych, do tego prowadzonych przez oddzielne zgrupowania kawalerii i piechoty;

- wykorzystania roli zaskoczenia w tzw. działaniach rajdowych;

- organizacji i prowadzenia walk w dużym mieście;

- znaczenia, zdobycia, utrzymania i kontroli nad węzłem komunikacyjnym dla przebiegu dłuższych walk oraz wykorzystania transportu;

- prowadzenia manewrów taktycznych polegających na ataku od czoła, wiążących siły przeciwnika oraz umiejętności obchodzenia skrzydeł;

- wykorzystania prowadzenia akcji oskrzydlających po zdobyciu mostów;

- wykorzystania sił odwodowych w zabezpieczeniu zdobytego terenu i jego oczyszczeniu z resztek niedobitków wroga.

Sami Rosjanie przeżyli klęskę w walkach o Wilno bardzo boleśnie. Wydano dyrektywę nr 1893/op. o otworzeniu położenia pod Wilnem ${ }^{68}$. W obronie Wilna dowodzone przez gen. Edwarda Śmigłego oddziały wojska polskiego, skutecznie zatrzymały ataki Rosjan z trzech stron, co jednak powinno być tematem innego opracowania.

Problem przynależności Wilna do Rzeczypospolitej był przedmiotem otwartego konfliktu z Republiką Litewską. 9 października 1921 r. „zbuntowane” oddziały 1 Dywizji Litewsko-Białoruskiej, pod dowództwem gen. Lucjana Żeligowskiego zajęły Wilno, tworząc nowy byt państwowy Litwę Środkową. W dniu 30 listopada 1921 r. ukazał się dekret gen. Żeligowskiego, w którym

${ }^{67}$ L. Wyszczelski, Niewypowiedziana wojna..., s. 88.

${ }^{68}$ Dyrektywa gtównodowodzącego Armii Czerwonej o odtworzeniu potożenia pod Wilnem z 25.04.1919 r., [w:] Аирективы главного командования Красной Армии (1917-1920). Сборник документов, Moskwa 1969, s. 78 -79. Rosjanie skierowali do walki 11500 bagnetów, 3000 szabel, 210 karabinów maszynowych i 45 dział. Vide: ibidem. Strona polska dysponowała w rejonie Wilna 6 batalionami 2 Dywizji Piechoty Legionów (ok. 6000 żołnierzy, 8 szwadronami Jazdy ppłk. Beliny-Prażmowskiego - stan 1150 żołnierzy i 18 dział). Oddziały te Piłsudski wzmocnił 1 i 2 batalionami z 1 Suwalskiego Pułku Piechoty - mjr. Mieczysława Mackiewicza, 3 batalionem 5 Pułku Piechoty Leg. kpt. Władysława Bortnowskiego i 2 batalionami 6 Pułku Piechoty Leg. - kpt. Włodzimierza Mazura-Bochenka, a wzmocnienie kawaleryjskie miało pochodzić z 4 Pułku Ułanów. 
ogłosił wybory do Sejmu Litwy Środkowej (8 I 1922), a następnie Sejm Litwy Środkowej (na swym dziesiątym posiedzeniu - 20 II 1922) proklamował przyłączenie tych obszarów do Polski ${ }^{69}$.

\section{BIBLIOGRAFIA}

\section{Źródła drukowane}

Аирективыглавного командования Красной Армии (1917-1920). Сборникдокументов, Москва 1969 (Direktivy glavnogo komandovaniya Krasnoy Armii (1917-1920). Sbornik dokumentov, Moskva 1969).

Dokumenty i materiaty do historii stosunków polsko-radzieckich, t. 2: Listopad 1918 - kwiecień 1920, oprac. W. Gostyńska, T. Kuźmiński, A. Leinwand, Warszawa 1961.

„Dziennik Rozkazów Wojskowych MSWojsk.” 1919, nr 57, poz. 1803.

Listy Józefa Pitsudskiego, oprac. K. Świtalski, „Niepodległośc” 1962, t. 7, s. 5-126.

Piłsudski J., Pisma zbiorowe Wybranie prac dotychczas drukiem ogtoszonych, t. 5-6, oprac. K. Świtalski; t. 7, oprac. J. Moszczeński, Warszawa 1937.

Sprawozdanie stenograficzne z 10 posiedzenie Sejmu z 20 lutego 1922, [w:] Sejm Wileński 1922. Przebieg posiedzeń wedtug sprawozdań stenograficznych wopracowaniu kancelarii sejmowej, Wilno 1922.

Stankiewicz W., Sześć listów Józefa Pitsudskiego do Stanistawa Szeptyckiego z okresu wojny polsko-radzieckiej, „Dzieje Najnowsze” 1971, nr 3, s. 157-173.

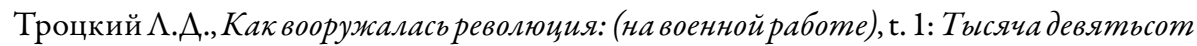
восемнадиатыий год, Москва 1923 (Trocki L., Kak vooruzhalas' revolyutsiya: (na voyennoy rabote), t. 1: Tysyacha devyat'sot vosemnadtsatyy god, Moskva 1923).

\section{Pamiętniki i wspomnienia}

Kaden-Bandrowski J., Wyprawa wileńska, Warszawa 1919.

Lipiński W., Od Wilna po Dynaburg. (Wspomnienia z ofensywy 5p.p. Legionów), Warszawa 1930.

Piskor T., Wyprawa wileńska, Warszawa 1919.

Szeptycki S., Front Litewsko-Biatoruski. 10 marca 1919 - 30 lipca 1920, Warszawa 2016.

Wejtko W., Samoobrona Litwy i Biatorusi. Szkice historyczne, Wilno 1930.

69 Sprawozdanie stenograficzne z 10 posiedzenie Sejmuz 20 lutego 1922, [w:] Sejm Wileński 1922. Przebieg posiedzeń wedtug sprawozdań stenograficznych w opracowaniu kancelarii sejmowej, Wilno 1922, s. X/1-22. 


\section{Opracowania}

Borzęcki J., Kiedy zaczęta się wojna polsko-sowiecka z lat 1919-1920? Rozważania z punktu widzenia polityczno-militarnego, „Dzieje Najnowsze” 2013, R. 45, z. 3, s. 25-37.

Czubiński A., Walka Józefa Pitsudskiego o nowy ksztatt polityczny Europy Środkowo-Wschodniej w latach 1918-1921, Toruń 2002.

Gierowska-Kałłaur J., Odczyt Marszatka Pitsudskiego wygtoszony w dniu 23 sierpnia 1923 roku w Wilnie, „Przegląd Wschodni” 1999, t. 5, z. 4, s. 767-791.

Komarnicki T., Pitsudski a polityka wielkich mocarstw zachodnich, Londyn 1952.

Ładoś A., Wasilewski w rokowaniach ryskich. (Wspomnienia osobiste), „Niepodległość” 1937, t. 16, s. 230-250.

Łossowski P., Konflikt polsko-litewski 1918-1920, Warszawa 1996.

Łossowski P., Stosunki polsko-litewskie w latach 1918-1930, Warszawa 1966.

Łukomski G., Langner Wtadystaw, [w:] Kawalerowie Virtuti Militari 1792-1945, t. 2: (1914-1945), cz. 1, Koszalin, s. 85-86.

Łukomski G., Polak B., Wrzosek M., Wojna polsko-bolszewicka 1919-1920, t. 1: 1 stycznia 1919 - 29 lutego 1920, red. B. Polak, Koszalin 1990.

Majchrowski J.M , Pierwsza Kompania Kadrowa. Portret oddziatu, Kraków 2002.

Materski W., Na widecie. II Rzeczpospolita wobec Sowietów 1918-1943, Warszawa 2005.

Mielcarek A.J., Węztowe zagadnienia ustrojowe Zarządu Cywilnego Ziem Wschodnich (1919-1920), w świetle aktów normatywnych, „Studia z Dziejów Państwa i Prawa Polskiego" 2011, t. 14, s. 241-251.

Nowak A., Polska i trzy Rosje. Studium polityki wschodniej Józefa Pitsudskiego (do kwietnia 1920 roku), Kraków 2002.

Ochmański J., Kulisy wyprawy wileńskiej Pitsudskiego z 1919 r., [w:] Z dziejów stosunków polsko-radzieckich. Studia i materiaty, t. 3, red. T. Cieślak i in., Warszawa 1968, s. $10-76$.

Okulewicz P., Koncepcje „międzymorza” w myśli i praktyce politycznej obozu Józefa Pitsudskiego w latach 1918-1926, Poznań 2001.

Pipes R., Rosja bolszewików, przekł. W. Jeżewski, Warszawa 2005.

Przybylski A., Dziatania wstęne w wojnie polsko-rosyjskiej 1918-1920, Warszawa 1928.

Przybylski A., Ofensywa na Wilno w kwietniu 1919 roku, Warszawa 1929.

Przybylski A., Wojna polska 1918-1921, Warszawa 1930.

Smoliński A., Jazda Rzeczypospolitej Polskiej w okresie od 12 X 1918 do 25 IX 1920, Toruń 2000.

Smoliński A., „Wyprawa wileńska” w kwietniu 1919, Szczecin 2020.

Śledziński K., Wojna polsko-bolszewicka. Konflikt, który zmienit bieg historii, Kraków 2020. 
Waligóra B., Dzieje 85 putku strzelców wileńskich, Warszawa 1928.

Waligóra B., Walki o Wilno: Okupacja Litwy i Biatorusi w 1918 r. - 1919 r. przez Rosje Sowiecka, Wilno 1938.

Wielhorski W., Polska a Litwa. Stosunki wzajemne w biegu dziejów, Londyn 1947.

Wojtaszak A., Generalicja Wojska Polskiego 1918-1926, Warszawa 2012.

Wyszczelski L., Niewypowiedziana wojna. Polsko-rosyjskie dziatania militarne w 1919 roku, Toruń 2005.

Wyszczelski L., Wilno 1919-1920, Warszawa 2008.

Wyszczelski L., Wojsko Polskie w latach 1918-1921, Warszawa 2006.

Żak A.C., Wilno 1919-1920, Warszawa 1993.

\section{Netografia}

Wlezień P., Wilno - walki w mieście 19-21 kwiecień 1919, http://phw.org.pl/wilno-walkiw-miecie-19-21-kwiecie-1919 (dostęp: 11 X 2020).

\section{Andrzej Wojtaszak}

\section{FIGHT FOR VILNUS 19-21 APRIL 1919}

Summary. During the fights for the borders of the Commonwealth after World War I (until 1921), Vilnius was occupied by four armies: the German (Ober-Ost), Soviet, Lithuanian and Polish. The presented study concerns the battles for Vilnius in April 1919. As part of the socalled the Vilnius offensive, troops of the cavalry rally group (1st Cavalry Brigade), commanded by Lt. Col. Władysław Belina-Prażmowski and the 2nd Legion Infantry Division, commanded by General Edward Śmigły-Rydz, took the city. In the three-day fights in the city, the inhabitants themselves played an important role, especially the railwaymen and workers from the Society of St. Kazimierz. The actions taken by the Polish troops resulted from the general assumptions of the Vilnius operation, were based on the concept of a quick cavalry raid, surprise the enemy and the seizure of important city facilities (railway station, barracks, river bank of the Willia). After three days, thanks to the support of the 2nd Legions Infantry Division, the city was seized. The experience of the fights for Vilnius $(200000)$ was to be used in the further period of the Polish-Bolshevik war. The city itself was seized in October 1921 (as a result of the „putsch”) by the army commanded by General Lucjan Żeligowski, and from March 1922 it finally became part of the Second Polish Republic.

Keywords: Vilnius, combat tactics, Vilnius offensive , 2nd Division of the Polish Legions, 1st Cavalry Brigade, Lt. Col. Władysław Belina-Prażmowski, General Edward Śmigły-Rydz, Józef Piłsudski 


\section{Załącznik nr 1}

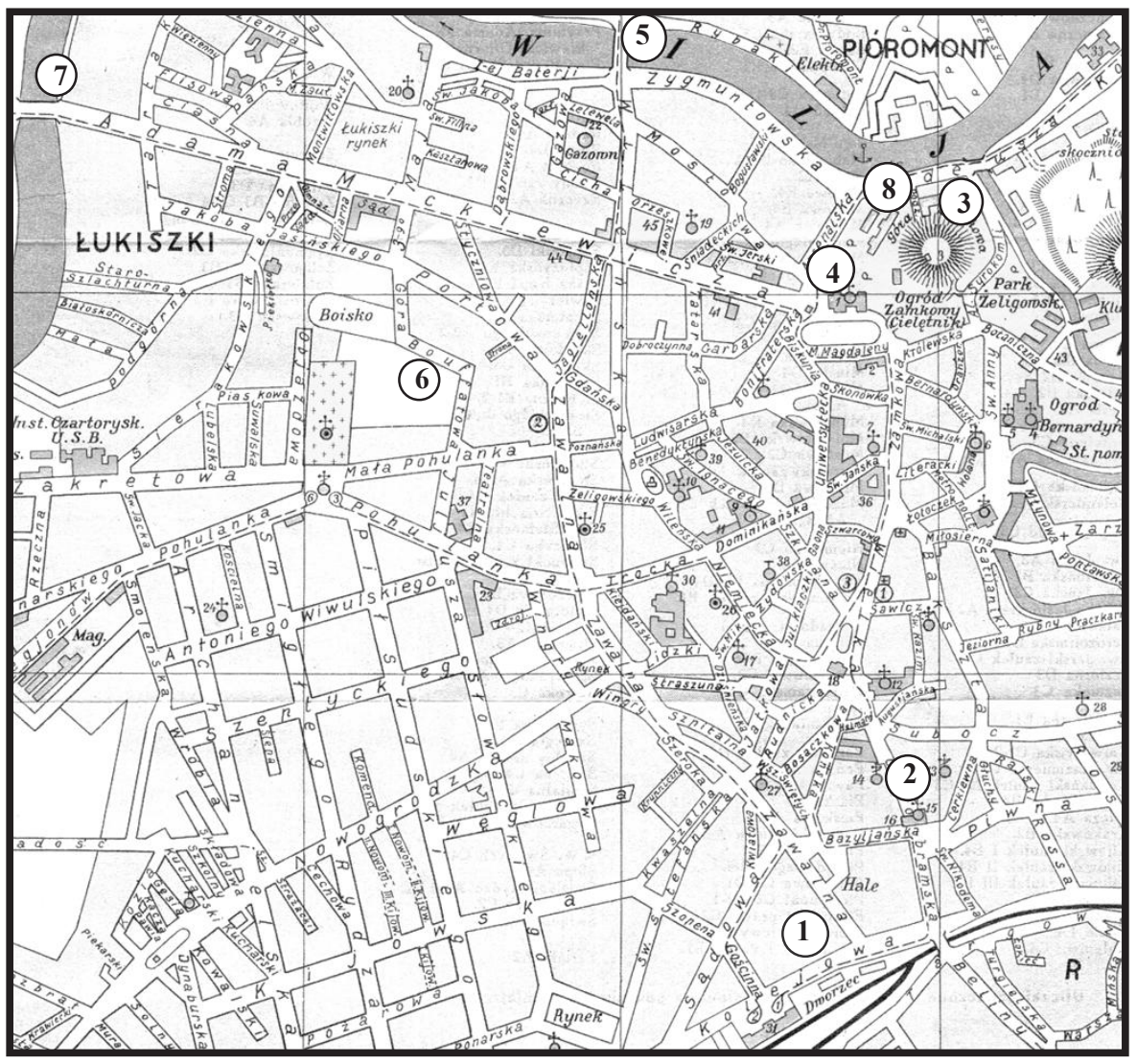

Mapa 1: Plan centrum miasta Wilno z zaznaczonymi ważniejszymi miejscami walk

\section{Legenda}

1. Dworzec kolejowy

2. Ostra Brama

3. Góra Zamkowa

4. Katedra i plac Katedralny
5. Zielony Most

6. Góra Bouffałowa

7. Most Zwierzyniecki

8. Koszary pod Górą (Kościół św. Stanisława)

Źródło: oprac. własne na podstawie fragmentu Planu Wilna z 1935, dodatek do Przewodnika po Polsce Związku Polskich Towarzystw Turystycznych, t. 1, red. W. JAMıŁKowskı. Archiwum Map Wojskowego Instytutu Geograficznego 1919-1939. 